КРИМЧУК С.Г.

\title{
ДО ПИТАННЯ ПОВІДОМЛЕННЯ ПРО ПІДОЗРУ ОКРЕМІЙ КАТЕГОРІЇ ОСІБ
}

Метою статті є аналіз нормативно-правової бази, що регламентує процедуру (порядок) повідомлення про підозру у кримінальних провадженнях відносно окремої категорії осіб. Так, у контексті конституційних засад рівності громадян перед законом і судом автор аналізує положення чинного кримінального процесуального законодавства України та інших нормативно-правових актів із питань, що стосуються надання окремій категорії осіб додаткових процесуальних гарантій. Вказано на недоліки процедури (порядку) повідомлення про підозру в досліджуваних провадженнях та обгрунтовано шляхи їх усунення. 3'ясовано, що поняття «правовий імунітет» характерне в цілому для вітчизняної правової теорії і активно використовується в різних галузях права, а не лише в доктрині кримінального процесу. Положення гл. 37 КПК України серед процесуальних особливостей провадження щодо окремої категорії осіб безпосередньо терміна «імунітет» не передбачають. Наголошено, що через відсутність у положеннях кримінального процесуального законодавства України нормативних приписів щодо розкриття змісту поняття «здійснення повідомлення про підозру» не існує доктринального підходу щодо суб'єкта (суб'єктів) складання та вручення повідомлення про підозру окремим категоріям осіб, у тому числі суддям. Визначено, що порядок притягнення до кримінальної відповідальності, що безпосередньо пов'язано з повідомленням про підозру (п. 14 ч. 1 ст. 3 КПК України), а також затримання й обрання запобіжного заходу стосовно досліджуваної категорії осіб, унормований лише щодо суддів і народних депутатів України (ст. 482 КПК України). Зроблено висновок, що процесуальний порядок кримінального провадження щодо окремої категорії осіб, особливо в частині повідомлення про підозру, законодавець здебільшого передбачив у такий спосіб, щоб досліджувана інституція не мала можливості належної практичної реалізації. У зв'язку із цим положення кримінального процесуального законодавства та інших нормативно-правових актів, що регулюють дане питання, потребують удосконалення.

Ключові слова: кримінальне провадження, окрема категорія осіб, імунітет, повідомлення про підозру, прокурор, підозрюваний.

The purpose of the article is to analyze the legal framework governing the procedure for reporting suspected criminal proceedings against a particular category of persons. Thus, in the context of the constitutional principles of equality of citizens before the law and the court, the author analyzes the provisions of the current criminal procedural legislation of Ukraine and other normative legal acts on issues related to the provision of additional procedural guarantees to a particular category of persons. The shortcomings of the procedure (order) of notification of suspicion in the investigated proceedings are indicated and the ways of their elimination are substantiated. It has been found that the concept of "legal immunity" is characteristic in general for the domestic legal theory and is actively used in various fields of law, and not only in the doctrine of criminal proceedings. The provisions of Sec. 37 of the CPC of Ukraine, among the procedural peculiarities of proceedings concerning a particular category of persons, do not directly imply the term "immunity". It is emphasized that due to the lack of normative prescriptions in the provisions of the criminal procedural legislation of Ukraine regarding disclosure of the content of the concept of "implementation of the suspicion notification" there is no doctrinal approach regarding the subject (s) to compile and hand over the suspicion

(C) КРИМЧУК С.Г. - аспірант наукової лабораторії із проблем протидії злочинності (Національна академія внутрішніх справ) 
notification to certain categories of persons, including judges. It has been determined that the procedure for criminal prosecution, which is directly related to the notification of suspicion (paragraph 14 of Part 1 of Article 3 of the CPC of Ukraine), as well as the detention and election of a preventive measure against the investigated category of persons, normalized only to judges and people deputies of Ukraine (Article 482 of the CPC of Ukraine). It was concluded that the procedural procedure for criminal proceedings against a particular category of persons, especially in the part of the report on suspicion, the legislator mostly provided in such a way that the investigated institution was not able to properly implement it. Due to this, the provisions of the criminal procedural legislation and other regulations governing this issue need improvement.

Key words: criminal proceedings, separate category of persons, immunity, notification of suspicion, prosecutor, suspect.

Вступ. Сьогодні практично всі конституції демократичних країн встановлюють формальну рівність перед законом для громадян, які проживають на їхніх територіях. Підтримуючи загальносвітові тенденції, вітчизняний законодавець у ст. 24 Конституції України закріпив норму-вимогу щодо рівності всіх перед законом, положення якої трансформовано в одну із загальних засад кримінального провадження - засаду рівності перед законом і судом (п. 3 ч. 1 ст. 7, ст. 10 КПК України). Утім, встановлені главою 37 КПК України особливості кримінального провадження щодо окремої категорій осіб представляють собою винятки із правил, встановлених зазначеною конституційною вимогою, які слід розцінювати не як якусь індульгенцію, а як певну гарантію від необгрунтованого кримінального переслідування у зв'язку зі здійсненням службових, професійних чи інших повноважень. У контексті розгляду даного питання особливої уваги набувають аспекти щодо особливостей повідомлення про підозру вказаній категорії осіб.

Аналіз останніх досліджень і публікацій. Проблемні питання досудового розслідування щодо окремої категорії осіб як загалом, так і в частині повідомлення їм про підозру, досліджували Ю.П. Аленін, С.С. Аскеров, І.В. Бабій, І.В. Главюк, О.І. Галаган, В.Г. Гончаренко, Н.С. Карпов, О.В. Капліна, А.М. Кислий, В.В. Лисенко, Л.М. Лобойко, М.А. Погорецький, С.В. Свириденко, Д.Б. Сергєєва, О.В. Сіренко, О.С. Старенький, О.Ю. Татаров, В.М. Тертишник, Л.Д. Удалова, В.М. Федченко, О.Г. Шило, А.В. Шевчишен та ін. Утім, деякі питання, що безпосередньо стосуються повідомлення про підозру досліджуваній категорії осіб, потребують подальшого дослідження.

Постановка завдання. Метою статті є аналіз нормативно-правової бази, що регламентує процедуру (порядок) повідомлення про підозру в кримінальних провадженнях відносно окремої категорії осіб.

Результати дослідження. Положення ст. 480 КПК України містять вичерпний перелік осіб, щодо яких здійснюється особливий порядок кримінального провадження. Утім, однією 3 тенденцій, що простежуються останнім часом у формуванні нормативної бази гл. 37 КПК України, $є$ поступове скорочення законодавцем як передбачених у ній процесуальних обмежень для досліджуваної категорії осіб, так і їх перелік.

У частині, що стосується меж процесуального імунітету, норми вищевказаної глави носять банкетний характер. Це означає, що, здійснюючи процесуальні дії та приймаючи передбачені законом рішення, суд, прокурор, слідчий мають враховувати не лише передбачені КПК України особливості провадження щодо даних осіб, але і положення інших нормативно-правових актів, зокрема Закони України «Про Уповноваженого Верховної Ради України із прав людини» від 23 грудня 1997 р. [1], «Про статус депутатів місцевих рад» від 11 липня 2002 р. [2], «Про запобігання корупції» від 14 жовтня 2014 р. [3], «Про вибори Президента України від 5 березня 1999 р.» [4], «Про Регламент Верховної Ради України» від 10 лютого 2010 р. [5], «Про забезпечення права на справедливий суд» від 12 лютого 2015 р. [6] тощо. Зі змісту цих законів слідує, що в їх текстах «приховані» процесуальні імунітети, що значно впливає на притягнення таких осіб до кримінальної відповідальності. Як результат, правоохоронні органи, здійснюючи кримінальне провадження на підставі та в порядку, передбаченому КПК України, можуть порушити окремі гарантії цих осіб, навіть не усвідомлюючи про можливість їх існування.

Згідно $з$ положеннями п. 2 ч. 1 ст. 480 КПК України до вищевказаної категорії осіб також відносяться судді, яким письмове повідомлення про підозру здійснюється Генеральним прокурором або його заступником (п. 3 ч. 1 ст. 481 КПК України). Дане положення конкретизовано в положеннях ч. 4 ст. 49 Закону України «Про судоустрій і статус суддів» від 2 червня 2016 р., 
де зазначається, що судді може бути повідомлено про підозру у вчиненні кримінального правопорушення лише Генеральним прокурором або його заступником [7]. За слушним визначенням C.С. Аскерова, вказані особливості кримінального провадження щодо професійного судді отримали назву «суддівський імунітет», який є синонімом поняття недоторканності суддів [8, с. 12]. Зазначимо, що поняття «правовий імунітет» характерне в цілому для вітчизняної правової теорії і активно використовується в різних галузях права, а не лише в доктрині кримінального процесу. Положення гл. 37 КПК України серед процесуальних особливостей провадження щодо окремої категорії осіб безпосередньо терміна «імунітет» не передбачають. Однак, виходячи з рішення Конституційного Суду України від 1 грудня 2004 р. № 19-рп/2004 про офіційне тлумачення положень частин 1, 2 ст. 126 Конституції України та ч. 2 ст. 13 Закону України «Про статус суддів» [9], у нас з'являється можливість встановити його зв' язок із даними кримінальними процесуальними нормами. Так, у вказаному рішенні зустрічаються як термін «імунітет», так і «недоторканність». На наш погляд, використовуючи у своїх офіційних рішеннях зазначені терміни, Конституційний Суд України тим самим фактично визнає наявність у чинному законодавстві правового імунітету, який у даному випадку є не особистим привілеєм судді, а одним із елементів його статусу, що має публічно-правове призначення - забезпечити здійснення правосуддя неупередженим, безстороннім і справедливим судом.

На сторінках юридичної літератури, зокрема, О.В. Гринюк та інші дослідники доречно звертали увагу на те, що через відсутність у положеннях кримінального процесуального законодавства України нормативних приписів щодо розкриття змісту поняття «здійснення повідомлення про підозру» не існує доктринального підходу щодо суб'єкта (суб'єктів) складання та вручення повідомлення про підозру окремим категоріям осіб, у тому числі суддям [10, с. 84]. Зрештою, означене питання було вирішено суддями Великої Палати Верховного Суду, які в Постанові від 8 листопада 2018 р. (справа № 800/536/17) виклали власну позицію. Зокрема, йдеться про те, що здійснення повідомлення про підозру особам, вказаним у главі 37 КПК України, не входить до кола повноважень слідчого або іншого прокурора, а отже, й не може бути їм доручене в порядку п. 4 ч. 2 ст. 36 КПК України. Генеральний прокурор або його заступник не вправі давати доручення про здійснення письмового повідомлення про підозру судді іншим службовим особам. Це виняткове повноваження Генерального прокурора або його заступника. Повідомлення про підозру судді має підписати і вручити саме Генеральний прокурор України або його заступник. Вручення повідомлення про підозру іншим прокурором є врученням його неналежною (неуповноваженою) особою [11].

Донині залишається законодавчо невизначеним процесуальний порядок повідомлення про підозру щодо Уповноваженого Верховної Ради України із прав людини (далі - Уповноваженого). Так, положення п. 2 ч. 1 ст. 481 КПК України лише передбачають, що письмове повідомлення про підозру Уповноваженого здійснюється Генеральним прокурором України (що виконує обов'язки Генерального прокурора). Однак ані в Конституції України, ані в Законах України «Про Уповноваженого Верховної Ради із прав людини» від 23 грудня 1997 р. [12], «Про державну службу» від 10 грудня 2015 р. [13], «Про Регламент Верховної Ради України» від 10 лютого 2010 р. та інших нормативних актах, що безпосередньо стосуються його діяльності, не закріплено жодної вимоги, яка б визначала особливість досліджуваного питання. Детальний аналіз окресленої нормативної бази вказує на те, що Уповноважений: а) користується правом недоторканності на весь час своїх повноважень; б) без згоди Верховної Ради України не може бути притягнутий до кримінальної відповідальності, затриманий, заарештований, підданий обшуку, а також особистому огляду; в) на те, що порядок надання відповідної згоди в Регламенті Верховної Ради України відсутній.

Як свідчить аналіз чинного кримінального процесуального законодавства, порядок притягнення до кримінальної відповідальності, що безпосередньо пов'язаний із повідомленням про підозру (п. 14 ч. 1 ст. 3 КПК України), а також затримання і обрання запобіжного заходу стосовно досліджуваної категорії осіб, унормований лише щодо суддів і народних депутатів України (ст. 482 КПК України). Так, особливості процедури повідомлення про підозру судді обговорювались нами раніше. У свою чергу, питання щодо зазначеної процедури стосовно народного депутата України здійснюється виключно за згодою Верховної Ради України, а отже, у спосіб, передбачений і для Уповноваженого. Із цього питання підтримаємо С.В. Свириденка та О.В. Сіренка в тому, що притягнення Уповноваженого до кримінальної відповідальності має здійснюватися в тому ж порядку, що й стосовно народного депутата України, а саме через надання згоди Верховної Ради України [14, с. 143; 15, с. 70].

На підставі викладеного вважаємо, що ст. 482 КПК України має бути доповнена окремою частиною, положення якої будуть стосуватися розгляду питань про притягнення до кримінальної відповідальності Уповноваженого безпосередньо через надання згоди Верховної Ради України. 
У контексті розгляду даного питання доречно звернути увагу на таких суб'єктів, як Голова або інші члени Рахункової палати, щодо яких у ст. 481 КПК України передбачено лише особливість вручення їм письмового повідомлення про підозру, яке здійснюється Генеральним прокурором (виконувачем обов'язки Генерального прокурора). Для вирішення окресленого завдання здійснимо аналіз окремих нормативних актів. Так, у ст. 20 Закону України «Про Рахункову палату» від 2 липня 2015 р. йдеться лише про те, що вказані посадовці призначаються та звільняються з посад Верховною Радою України. Однією із причин звільнення є набрання стосовно них законної сили обвинувальним вироком суду [16]. Натомість у положеннях ст. 37 Закону України «Про Рахункову палату» від 11 липня 1996 р. передбачалося, що Голова Рахункової палати, Перший заступник і заступник Голови, головні контролери та Секретар Рахункової палати не можуть бути затримані, притягнуті до кримінальної відповідальності без згоди Верховної Ради України [17]. Отже, законодавець у чинній редакції Закону з даного питання втратив будь-яку конкретику. Задля внормування процедури притягнення Голови або інших членів Рахункової палати до кримінальної відповідальності доцільно внести зміни до ст. 482 КПК України.

Положення п. 7 ч. 1 ст. 480 КПК України до окремої категорії осіб також відносять адвоката. На жаль, порядок провадження процесуальних дій стосовно адвокатів порушується у зв'язку 3 нечіткою регламентацією даних аспектів у чинному законодавстві. Здебільшого це стосується певних особливостей проведення обшуку чи огляду житла, іншого володіння адвоката, приміщень, де він безпосередньо здійснює свою діяльність, тимчасового доступу до його речей і документів, а також повідомлення про їх проведення Ради адвокатів регіону. Особливе місце поміж вказаних аспектів займають питання щодо процедури притягнення адвокатів до кримінальної відповідальності. Так, відповідно до п. 13 ч. 1 ст. 23 Закону України «Про адвокатуру та адвокатську діяльність» повідомлення про підозру адвоката у вчиненні кримінального правопорушення може бути здійснене виключно Генеральним прокурором України, його заступником, прокурором Автономної Республіки Крим, області, м. Києва та м. Севастополя [18]. Утім, положення п. 1 ч. 1 ст. 481 КПК України передбачають, що зазначені дії виконує Генеральний прокурор, його заступник або керівник регіональної прокуратури в межах своїх повноважень. Вказана розбіжність викликана прийняттям Закону України «Про прокуратуру» від 14 жовтня 2014 р., положення якого не знайшли відображення в Законі України «Про адвокатуру та адвокатську діяльність».

Проблемні питання, що стосуються повідомлення про підозру адвокату, стали предметом науково-практичного дискусійного обговорення на тему «Гра поза правилами: проблемні питання пред’явлення підозри спеціальному суб'єкту та іiї обгрунтованість. Різні підходи до правозастосування», проведеного Національною асоціацією адвокатів України 11 вересня 2017 р. [19]. У його основу були покладені питання щодо відмежування повідомлення про підозру як процесуального рішення від такої самої процесуальної дії. Оскільки з огляду на наявність особливого порядку кримінального провадження це зумовлює необхідність встановлення суб'єкта, що вповноважений прийняти вказане рішення, а також вручити повідомлення про підозру.

Згодом, а саме 23 вересня 2017 р. Рада адвокатів України своїм рішенням № 222 затвердила роз'яснення положення пункту 13 частини першої статті 23 Закону України «Про адвокатуру та адвокатську діяльність» у частині підписання, повідомлення та/або вручення повідомлення про підозру адвокату як спеціально визначеному суб'єкту кримінального провадження, згідно 3 яким «термін «виключно», який вживається в пункті 13 частині першій статті 23 Закону, свідчить про відсутність процесуальних повноважень у прокурора на надання доручень, передбачених статтею 36, 40 КПК України» [20]. Із цього слідує, що дане питання безальтернативно вирішилось на користь статусу адвоката, отже, в дискусії окремих теоретиків та практиків із розширеного тлумачення приписів досліджуваних норм поставлена крапка.

Положення КПК України мають ряд правових інститутів, що мають на меті конкретні, виняткові ситуації, які до сьогоднішнього дня не отримали своєї практичної реалізації. Так, складно уявити, що суб'єктом злочину може стати Генеральний Прокурор. Однак навіть найменша можливість виникнення подібної ситуації зумовлює науковий інтерес до аналізу п. 4 ч. 1 ст. ст. 481 КПК України, які поширюють свою дію на зазначеного посадовця. Досліджуваний порядок кримінального провадження щодо Генерального прокурора означає, що воно здійснюється за загальними правилами, передбаченими КПК України, з урахуванням відповідних особливостей, визначених у положеннях глави 37 КПК України. Перш за все, це стосується письмового повідомлення про підозру Генеральному прокурору, що здійснюється заступником Генерального прокурора (п. 4 ч. 1 ст. 481 КПК України). Із приписів вказаної норми слідує, що законодавець від органів прокуратури до окремої категорії осіб, щодо яких застосовується особливий порядок кримінального 
провадження в разі притягнення їх до кримінальної відповідальності, відносить лише Генерального прокурора України, його заступника, прокурора Спеціалізованої антикорупційної прокуратури. Утім, згідно зі ст. 121 Конституції України та ст. 7 Закону України «Про прокуратуру» органи прокуратури становлять єдину систему (державну установу) - прокуратуру України, яку очолює керівник - Генеральний прокурор України. Єдність вказаної системи забезпечується єдиним статусом прокурорів, на яких покладаються однакові функції. У зв'язку із цим у положеннях ст. 481 КПК України доречно використовувати саме термін «прокурор», який уособлює в собі всіх посадовців прокуратури України. Окреслене нами питання вже знайшло своє відображення в такий спосіб у законодавстві окремих країн пострадянського простору, зокрема в п. 6 ч. 1 ст. 468-1 КПК Республіки Білорусь [21], п. с ч. 1 ст. 8 Закону Республіки Грузія від 21 жовтня 2008 р. «Про прокуратуру в Республіці Грузія» [22].

Аналіз інших положень законодавства, що стосується порядку притягнення до кримінальної відповідальності Генерального прокурора, вказує на його суцільну недосконалість. Так, у ч. 1 ст. 40 Закону України «Про прокуратуру» йдеться лише про те, що він призначається на посаду Президентом України за згодою Верховної Ради України, а однією з підстав для звільнення 3 посади, згідно п. 5 ч. 1 ст. 51 вищевказаного Закону, є набрання законної сили обвинувальним вироком суду щодо нього. Разом із тим питанням, що стосуються дисциплінарної відповідальності прокурора, присвячується окремий розділ. Отже, процедура повідомлення про підозру Генеральному прокурору також $є$ законодавчо не визначеною.

Із метою вдосконалення досліджуваного інституту пропонуємо конкретизувати положення ст. 481 КПК України, що стосуються даного питання, а саме: п. 1 ч. 1 ст. 481 після слів «міському голові - » доповнити словом «лише»; п. 2 ч. 1 ст. 481 після слів «члену Національного антикорупційного агентства 3 питань запобігання корупції-» доповнити словом «лише»; п. 3 ч. 1 ст. 481 після слів «працівникам Національного антикорупційного бюро України - » доповнити словом «лише»; п. 4 ч. 1 ст. 481 після слів «Генеральному прокурору - доповнити словом «лише».

Вказане повністю узгоджується із прецедентною практикою ЄСПЛ, який особливу увагу звертає саме на належного суб'єкта висунення офіційного обвинувачення особі, тобто йдеться про припущення, що нею вчинено кримінально каране правопорушення в рішеннях від 14 жовтня 2010 р. у справі «Бруско проти Франції» (Brusco v. France) (№ 1466/07), від 27 лютого 1980 р. у справі «Девеєр проти Бельгії» (Deweer v. Belgium) (№ 6903/75), від 15 липня 1982 р. у справі «Екле проти Німеччини» (Eckle v. Germany) (№ 8130/78), від 7 жовтня 2016 р. у справ «Зосимов проти України» (Zosymov v. Ukraine) (№ 4322/06) [23; 24; 25; 26].

У контексті викладеного С.С. Свириденко небезпідставно звертає увагу на те, що Генеральний прокурор (який виконує обов'язки Генерального прокурора), його заступник - це посадові особи, передбачені Законом України «Про прокуратуру», але не їхній процесуальний статус. Таке питання виникає з огляду на те, що, не маючи жодного відношення до кримінального провадження, зокрема не будучи процесуальними керівниками або включеними до групи прокурорів, останні не вповноважені здійснювати жодних процесуальний дій. Тому вбачається цілком логічним, що в разі проведення досудового розслідування щодо окремої категорії осіб за необхідності до складу групи прокурорів слід включати Генерального прокурора (який виконує обов'язки Генерального прокурора), його заступника та керівника регіональної прокуратури, із винесенням про це відповідної постанови [15, с. 146]. Погляди дослідника повністю підтримуємо, оскільки згідно 3 п. 15 ст. 3 КПК України прокурор - це особа, яка обіймає посаду, передбачену ст. 17 Закону України «Про прокуратуру», та діє в межах своїх повноважень. Прокурор набуває повноважень у кримінальному провадженні лише після того, як керівник прокуратури згідно 3 положеннями, передбаченими ч. 1 ст. 37 КПК України, призначить його процесуальним керівником. Тим більше, повідомляти про підозру у вчиненні кримінального правопорушення уповноважений лише прокурор - процесуальний керівник (п. 11 ч. 2 ст. 36 КПК України). У даному випадку для Генерального прокурора (що виконує обов'язки Генерального прокурора) та його заступника право повідомляти особі про підозру буде безпосередньо випливати з функції процесуального керівництва, а не процесуального нагляду за прокурорами нижчого рівня.

Висновки. На підставі викладеного приходимо до висновку, що процесуальний порядок кримінального провадження щодо окремої категорії осіб, особливо в частині повідомлення про підозру, законодавець здебільшого передбачив у такий спосіб, щоб досліджувана інституція не мала можливості належної практичної реалізації. У зв'язку із цим положення кримінального процесуального законодавства та інших нормативно-правових актів, що регулюють дане питання, потребують удосконалення. 


\section{Список використаних джерел:}

1. Про Уповноваженого Верховної Ради України з прав людини : Закон України від 23 грудня 1997 року № 776/97-ВР. Відомості Верховної Ради Украӥни. 1998. № 20. Ст. 99.

2. Про статус депутатів місцевих рад: Закон України від 11 липня 2002 року № 93-IV. Відомості Верховної Ради України. 2002. № 40. Ст. 290.

3. Про запобігання корупції : Закон України від 14 жовтня 2014 року № 1700-VII. Відомості Верховної Ради України. 2014. № 49. Ст. 2056.

4. Про вибори Президента України : Закон України від 5 березня 1999 року № 474-XIV. Відомості Верховної Ради Украӥни. 1999. № 14. Ст. 81.

5. Про Регламент Верховної Ради України : Закон України від 10 лютого 2010 року № 1861-VI. URL : http://zakon2.rada.gov.ua/laws/show/1861-17.

6. Про забезпечення права на справедливий суд : Закон України від 12 лютого 2015 року № 192-VIII. Відомості Верховної Ради Украӥни. 2015. № 18. № 19-20. Ст. 132.

7. Про судоустрій і статус суддів : Закон України від 2 червня 2016 р. № 1402-VIII. Відомості Верховної Ради України. 2016. № 31. Ст. 545.

8. Аскеров С.С. Принцип незалежності і недоторканності суддів у кримінальному процесу України та Азербайджану : автореф. дис. ... канд. юрид. наук : 12. 00.09. Київ, 2008. 20 с.

9. Рішення Конституційного Суду України у справі за конституційним поданням Верховного Суду України про офіційне тлумачення положень частин першої, другої статті 126 Конституції України та частини другої статті 13 Закону України «Про статус суддів» (справа про незалежність суддів як складову їхнього статусу) від 01.12.2004 p. № 19-pп/2004. URL : https://zakon.rada.gov.ua/laws/show/v019p710-04?find =1\&text=\%B3\%EC\%F3\%ED $\% \mathrm{~B} 3 \% \mathrm{~F} 2 \%$ E5\%F2Hw11.

10. Гринюк В., Старенький О. Проблемні питання повідомлення про підозру судді у кримінальному провадженні. Право України. 2017. № 12. С. 82-94.

11. Окрема думка суддів Великої Палати Верховного Суду щодо Постанови від 8 листопада 2018 року у справі № 800/536/17. URL : http://www.reyestr.court.gov.ua/Review/ 78426375 .

12. Про Уповноваженого Верховної Ради України з прав людини : Закон України вid 23.12.1997 p. № 776/97-BР. Відомості Верховної Ради України. 1998. № 20. Ст. 99.

13. Про державну службу : Закон України від 10.12.2015 p. № 8890-VIII. URL : http://zakon.rada.gov.ua.

14. Свириденко С.С. Досудове розслідування у кримінальному провадженні щодо осіб, які користуються недоторканністю : дис. ...канд. юрид. наук : 12. 00.09. Ірпінь, 2018. 232 с.

15. Сіренка О.В., Ковбасюк В.А. Особливості кримінального провадження щодо уповноваженого верховної ради України з прав людини. Міжнародний юридичний вісник: збірник наукових праць Національного університету державної податкової служби України. 2016. Вип. 1(3). С. 65-71.

16. Про Рахункову палату : Закон України від 2 липня 2015 р. № 576-VIII. Biдомості Верховної Ради. 2015. № 36 Ст. 360.

17. Про Рахункову палату : Закон України від 11 липня 1996 року № 315/96-ВР. Відомості Верховної Ради України. 1996. № 43. Ст. 212.

18. Про адвокатуру та адвокатську діяльність : Закон України від 5 липня 2012 р. № 5076VI. URL : http://zakon4.rada.gov.ua/laws/show/5076-17.

19. Гра поза правилами: проблемні питання пред'явлення підозри спеціальному суб'єкту та ії обгрунтованість. Різні підходи до правозастосування». Національна асоціація адвокатів України 11 вересня 2017 p. URL : https://unba.org.ua/assets/uploads/26569b0fb3685970dcb3 file.pdf.

20. Рішення Ради адвокатів України про затвердження роз'яснення пункту $1 \overline{3}$ частини першої статті 23 Закону України «Про адвокатуру та адвокатську діяльність» від 23 вересня 2017 року № 222. URL : http://unba. org.ua/assets/uploads/legislation/rishennya/2017-09-23-rshennya-rau-222_59d4f61c29010.pdf.

21. Уголовно-процессуальный кодекс Республіки Белорусь. URL : http://www. pravo.levonevsky.org/kodeksby/upk.

22. Закон Республіки Грузія «Про прокуратуру в Республіці Грузія» від 21 жовтня 2008 року. URL : http://pravo.org.ua/files/zarub_zakon/GR_PR_2008.pdf.

23. Постановление Европейского суда по правам человека от 14.10.2010 «Бруско против Франции» (Brusco v. France) (№ 1466/07). URL : https://zakonbase.ru/content/base/181893/. 
24. Постановление Европейского суда по правам человека от 27.02.1980 «Девеер против Бельгии» (Deweer v. Belgium) від (№ 6903/75). URL : http://cambodia.ohchr.org/sites/default/files/ echrsource/Deweer\%20v.\%20Belgium\%20 [27\%20Feb\%201980]\%20[EN].pdf .

25. Решения Европейского суда по правам человека по делу «Экле против Федеративной Республики Германии» от 15 июля 1982 г. URL : http://www.echr.ru/documents/ doc/2461443/2461443.htm.

26. Рішення ЄСПЛ від 7 жовтня 1016 року у справі «Зосимов проти України» (Zosymov v. Ukraine), заява № 4322/06. URL : https://zakon.rada.gov.ua/laws/show/974_c94.

УДК 343.2

DOI https://doi.org/10.32844/2618-1258.2019.6.48

МІРКОВЕЦЬ В.І.

\title{
ПРАВО НА СВОБОДУ ТА ОСОБИСТУ НЕДОТОРКАННІСТЬ ПІД ЧАС ЗАСТОСУВАННЯ ЗАХОДІВ ЗАБЕЗПЕЧЕННЯ КРИМІНАЛЬНОГО ПРОВАДЖЕННЯ В МІЖНАРОДНИХ ПРАВОВИХ АКТАХ ТА ЗАКОНОДАВСТВІ УКРАЇНИ
}

\begin{abstract}
Метою статті є дослідження змісту деяких міжнародних документів та законодавства України, що стосуються визначення поняття права на свободу та особисту недоторканність. 3'ясування його місця у загальній концепції прав людини, особливостей забезпечення під час застосування заходів забезпечення кримінального провадження. Так, у статті досліджено положення, що стосуються права на свободу та особисту недоторканність у міжнародному та національному праві: Загальна декларація прав людини, Міжнародний пакт про громадянські і політичні права, Конвенція про захист прав людини і основоположних свобод, рішення ЄСПЛ, Конституція України, КПК України, юридичні позиції Конституційного Суду України (щодо зв'язку права на свободу та особисту недоторканність з іншими правами, деяких аспектів тлумачення поняття «недоторканність», визначення свободи і особистої недоторканості як одного з визначальних та фундаментальних конституційних прав людини, випадків і умов обмеження права на свободу і особисту недоторканність, механізму забезпечення права на свободу і особисту недоторканність). Наголошено, що кожному заарештованому чи затриманому має бути невідкладно повідомлено про мотиви арешту чи затримання, роз'яснено його права та надано можливість 3 моменту затримання захищати себе особисто та користуватися правовою допомогою захисника. Зроблено висновок, що міжнародне і внутрішнє право в цілому розкривають сутність забезпечення права на свободу і особисту недоторканність. Системний аналіз міжнародних та національних документів щодо права на свободу і особисту недоторканність показав, що внутрішнє право переважно відповідає міжнародним документам у контексті позитивних зобов'язань держави щодо забезпечення такого права. Проте низка недоліків нормативної регламентації, а отже, і правозастосування, пов'язані як визначенням правомірних випадків обмеження такого права, так і регламентацією прав, що передбачені для його захисту. Тобто не у кожному випадку обмеження права на свободу й особисту недоторканність під час застосування заходів забезпечення кримінального провадження визначено процесуальне право, необхідне для його охорони та/або захисту.

Ключові слова: право на свободу та особисту недоторканність, міжнародні правові акти, Кримінальний процесуальний кодекс Украӥни, Конституція Украӥни, Конституиійний Суд Украӥни, законодавство.
\end{abstract}

(C) МІРКОВЕЦЬ В.І. - здобувач аспірантури (Відкритий міжнародний університет розвитку людини «Україна») 